\title{
Designing a Photovoltaic Solar Energy System for a Commercial Building Case Study: Rosa Park Hotel in Khartoum-Sudan
}

\author{
Asim M. Widatalla ${ }^{1, *}$, Heimo Zinko ${ }^{2}$ \\ ${ }^{1}$ Linkoping University, Dept. of Thematic Studies, Water and Environmental Studies, Linkoping, Sweden. \\ ${ }^{2}$ Linköping University, Department of Management and Engineering, Energy Systems, Linkoping, Sweden \\ * Corresponding author. Tel: +46 707165268,E-mail: asiwi224@student.liu.se
}

\begin{abstract}
Instability of electricity supply in Sudan is an increasing problem, especially in the capital and other larger cities. Commercial users such as hotels are looking for alternative solutions in order to be able to deliver adequate standards to their guests. In this study we investigate and optimize combined PV/Diesel system as a main electricity source for a hotel. There is significant potential for the use of the photovoltaic solar energy in countries like Sudan which receive abundant amounts of solar radiation around the year; the present work aims to design a rooftop photovoltaic solar system, or a hybrid system (Solar and Diesel) to produce $88100 \mathrm{kWh} / \mathrm{yr}$ of electricity for Rosa Park Hotel in Khartoum. The aim of this feasibility study was to find economic and useful combinations between Diesel and PV systems based on actual electricity consumption data of the hotel, taking into consideration both economic and environmental system aspects.

The study shows that, the PV systems can be used independently or together with the Diesel generator as a replacement energy resource. Due to the high initial cost of the installation of a PV stand-alone systems, the economic optimizations shows that a combination of a relatively small Diesel aggregates with a PV system can result in low system costs taking advantage of free and clean solar energy of PV and the system flexibility of a Diesel system.
\end{abstract}

Keywords: HOMER, Hybrid system, Photovoltaic Solar Energy, Renewable Energy, Sudan.

\section{Introduction}

Sudan Fig. 2 is a country located in northeastern of Africa, with high solar radiation, according to Abdeen, (1997), the average sunlight hours in the capital- Khartoum - range between 8.7 hours per day in July and 10.5 hours per day in February [1], this gives a yearly average of sunlight hours 9.92 per day, and around 3600 hours/year. On the real side: the country faces a serious problem of instability of electricity supply especially in the capital and the main big cities. The hydro-power generators could not feed their rated electricity supply mainly in the rainy season - April to October - because of the accumulation of the mud in the dams. There are some other factors that make the problems of electricity supply and demand in urban areas bigger than similar problems in rural areas, such as the constant increase of population and building density.

Figure 1: Map of Sudan [2]

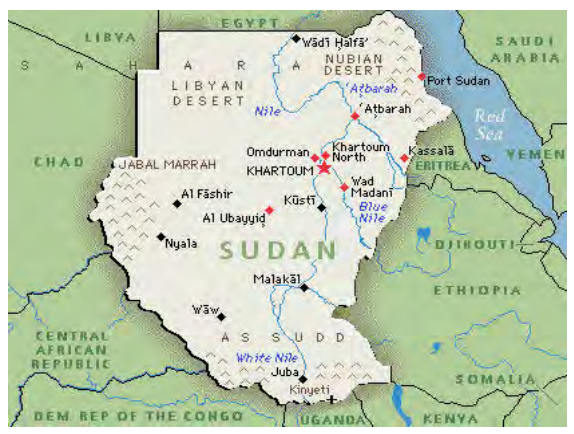

The aim of this study is to find out how the solar energy can be used to produce electricity for a hotel in Sudan, the task is to design a stand-alone PV system, and a Solar/Diesel system, and then to compare those regarding cost-effectiveness and environment. 


\subsection{Rosa park hotel}

Rosa Park Hotel is a new four stars hotel located at the city center of Khartoum, there are 66 rooms spread across five floors, In addition to the health club service and fitness center.
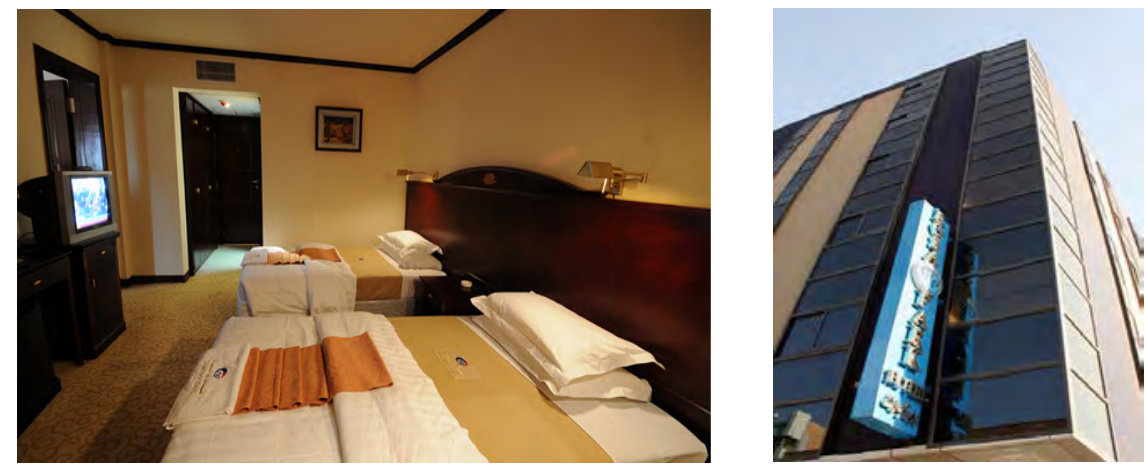

Figure 2: Photos from Rosa Park Hotel. [3]

\subsection{Photovoltaic System}

For this study, a commercial polycrystalline silicon solar cell was chosen at offered fixed price for the installation. Besides the solar cells, there are other important components in the PV-system, such as the inverter that is used to convert the direct current DC from the solar modules to alternating current AC, in our case synchronous with the grid. Furthermore, due to the variability of sunshine on both daily and seasonable basis, the mismatching between the production and the consumption of the electricity must be balanced by a battery system. [4].

\subsection{Methodology}

The methodology that we used for this study included the preparation of the inputs and calculations that are required for the simulation process. These inputs can be technical specifications of the PV panels, batteries, generators, etc., or the characteristics of the plant size, such as the weather data of the area where the system will be build on, the solar radiation density to which the plant site is exposed and the annual average temperature of the specific area. Also the economical inputs such as the capital costs and costs for replacement, operation and maintenance of the different equipment are of great importance for the financial evaluation.

A commercial software HOMER (Hybrid Optimization Model for Electric Renewables) was chosen for simulation purposes. HOMER is a computer model first developed by National Renewable Energy Laboratory, (USA-DOE). It is based on hour to hour simulation and this gives possibilities to control the battery status and to determine the sizing of the batteries [5]. The program determines the energy production for a given system over a defined period and calculates investment and operational costs. Because of the possibility of handling multiple inputs, HOMER can in short time calculate a multitude of optional system solutions and by that way an optimal system solution can be found.

\section{Energy specifications}

\subsection{Electrical loads}

The primary load distribution is essential for the designing process because the variation of the load through the day and night will affect the number of PV panels, and hence the capacity of storage battery and inverter: 
- $\quad$ There are different loads for different seasons, the load will be $300 \mathrm{kWh} /$ day for the tourists season (from October till February), and $200 \mathrm{kWh} /$ day for the normal season (from March till September).

- $\quad$ The power consumption will vary according to the daily activities, for example; most of the work in the kitchen, rooms cleaning and the laundry used to be during the day.

The following tables show the loads for the two seasons per hour during day and night.

Table 1: The load of the tourist season

\begin{tabular}{cccccccc}
\hline Time & $\begin{array}{c}\text { Load } \\
\mathrm{kW}\end{array}$ & Time & $\begin{array}{c}\text { Load } \\
\mathrm{kW}\end{array}$ & Time & $\begin{array}{c}\text { Load } \\
\mathrm{kW}\end{array}$ & Time & $\begin{array}{c}\text { Load } \\
\mathrm{kW}\end{array}$ \\
\hline 00:00 - 01:00 & 3.0 & $06: 00-07: 00$ & 7.0 & $12: 00-13: 00$ & 20.0 & $18: 00-19: 00$ & 15.0 \\
01:00 - 02:00 & 3.0 & $07: 00-08: 00$ & 10.0 & $13: 00-14: 00$ & 25.0 & $19: 00-20: 00$ & 15.0 \\
02:00 - 03:00 & 3.0 & $08: 00-09: 00$ & 15.0 & $14: 00-15: 00$ & 25.0 & $20: 00-21: 00$ & 10.0 \\
03:00 - 04:00 & 3.0 & $09: 00-10: 00$ & 15.0 & $15: 00-16: 00$ & 25.0 & $21: 00-22: 00$ & 8.0 \\
04:00 - 05:00 & 3.0 & $10: 00-11: 00$ & 15.0 & $16: 00-17: 00$ & 25.0 & $22: 00-23: 00$ & 6.0 \\
05:00 - 06:00 & 3.0 & $11: 00-12: 00$ & 20.0 & $17: 00-18: 00$ & 20.0 & $23: 00-00: 00$ & 6.0 \\
\hline
\end{tabular}

Table 2: The load of the normal season

\begin{tabular}{cccccccc}
\hline Time & $\begin{array}{c}\text { Load } \\
\mathrm{kW}\end{array}$ & Time & $\begin{array}{c}\text { Load } \\
\mathrm{kW}\end{array}$ & Time & $\begin{array}{c}\text { Load } \\
\mathrm{kW}\end{array}$ & Time & $\begin{array}{c}\text { Load } \\
\mathrm{kW}\end{array}$ \\
\hline 00:00 - 01:00 & 2.0 & $06: 00-07: 00$ & 3.0 & $12: 00-13: 00$ & 13.0 & $18: 00-19: 00$ & 10.0 \\
$01: 00-02: 00$ & 2.0 & $07: 00-08: 00$ & 6.0 & $13: 00-14: 00$ & 18.0 & $19: 00-20: 00$ & 10.0 \\
$02: 00-03: 00$ & 2.0 & $08: 00-09: 00$ & 10.0 & $14: 00-15: 00$ & 18.0 & $20: 00-21: 00$ & 8.0 \\
$03: 00-04: 00$ & 2.0 & $09: 00-10: 00$ & 10.0 & $15: 00-16: 00$ & 18.0 & $21: 00-22: 00$ & 4.0 \\
$04: 00-05: 00$ & 2.0 & $10: 00-11: 00$ & 10.0 & $16: 00-17: 00$ & 18.0 & $22: 00-23: 00$ & 3.0 \\
05:00 - 06:00 & 2.0 & $11: 00-12: 00$ & 13.0 & $17: 00-18: 00$ & 13.0 & $23: 00-00: 00$ & 3.0 \\
\hline
\end{tabular}

\subsection{Solar radiation}

The average global solar radiation on the horizontal surface for each hour of the year will be needed for designing a PV system in a specific location. Here for this study, the solar plant was suggested to be located in Khartoum in Sudan at a location of $15^{\circ} 31^{\prime} \mathrm{N}$ latitude and $32^{\circ} 35^{\prime} \mathrm{E}$ longitude. The hourly solar radiation data was obtained from the NASA Surface Meteorology and Solar Energy web site [6]. The annual average of the daily solar radiation on a horizontal surface for this area is $6.31\left(\mathrm{kWh} / \mathrm{m}^{2} / \mathrm{d}\right)$.

\section{Optimization}

By feeding the software with the required basic input data, HOMER starts the work by running an hourly simulation of all possible configurations of different system types, and performs energy balance calculations for each hour in the year. The optimization process generates a list of configurations, sorted by net present cost, which can be used for the comparison of the different system design options [7]. An example is shown in Figure 3.

Three main types of system solutions have been investigated: PV stand-alone system, Hybrid system (PV + Diesel) and Diesel generator system (reference case). The size of PV system, Battery system and inverter system is depicted in Figure 3. 


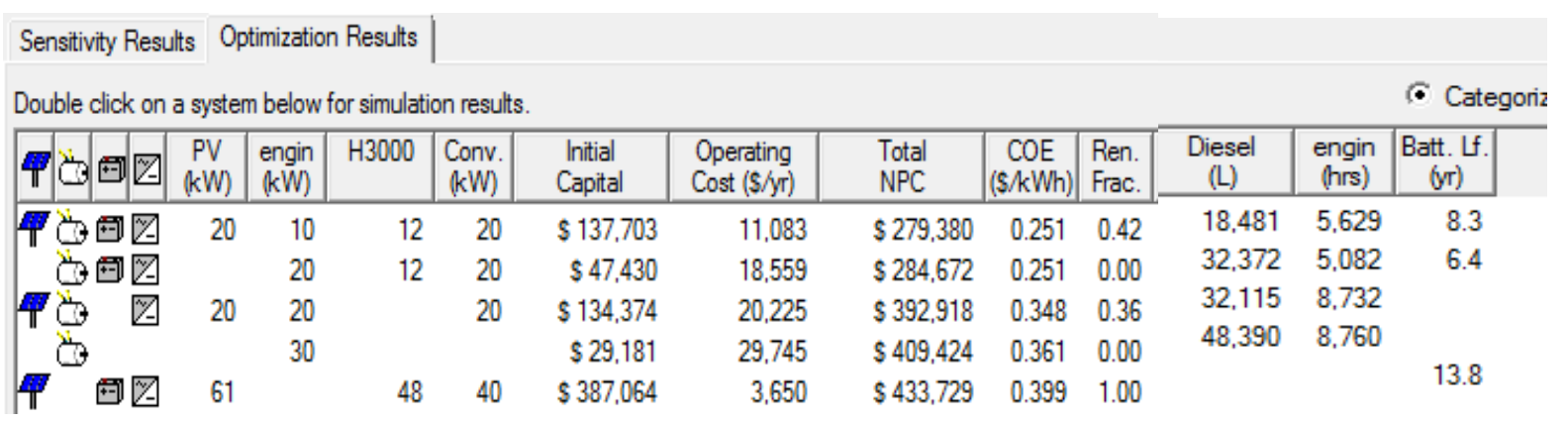

Figure 3: Optimization results generated by Homer.

The headers in Figure 3 have the following meanings: engin - diesel engine, H3000 means 1 set of storage battery type of Hoppecke $24 \mathrm{OPzS}$ (3000 Ah), Conv. is for converter, Ren. Frac. is for Renewable fraction of generated electricity, and Batt. Lf. is for battery lifetime, besides the symbols of PV panel, diesel engine, battery and converter are also included.

\subsection{Economic parameters}

The investment costs are described in Table 3. The costs include the hardware, the installation on the site and the connection to the grid. Beside the initial investment, we have to take into account replacement of equipment which is worn out. Hence replacement costs are added to the generation cost, when the lifetime of equipment has been reached. For batteries, the life time is different depending on the number of charging cycles and depth of the discharge. This is the reason for varying battery lifetimes in different systems. The time frame of the financial analysis of this project is 25 years. The interest rate was taken to $6 \%$.

The economical evaluation of the project can be calculated based on the inputs of financial aspects, which include the cost of the system components that the hotel's owner will pay, and on the other hand the benefits that the owner will earn from the projects.

- $\quad$ Projected Benefits = Value of Generated Electricity + Value of Excess Energy

+ Value of $\mathrm{CO}_{2}$ Reduced

- $\quad$ Electricity Costs = Capital Costs + Replacement Costs + Periodic Costs.

The annuity calculations of all the benefits, the costs and also the Net Present Value were done based on assumed 25 years lifetime of the PV panels. The lifetime of the batteries is varying according to their use (see sect. 3.2.2) and the life time of the inverter is 15 years. Replacement costs are shown in Table 4.

\subsubsection{Value of electricity}

For the evaluation purpose of this system, we will use the electricity price that is achieved by the Diesel generator as a reference in order to calculate the projected benefit - because Diesel generators are widely used to produce the electricity in the areas of instable electricity supply. Therefore, According to the summary of the results in Table 7 the annual saving due to the electricity production is:

$=$ the generated electricity through the year $(\mathrm{kWh} / \mathrm{yr}) *$ Diesel generated electricity price $(\$)$ $=88100 \mathrm{kWh} / \mathrm{yr} * 0.251(\$ / \mathrm{kWh})=22113.1(\$ / \mathrm{yr})$.

Eventual excess energy (which is produced by the stand-alone system) is assumed to be sold to neighbors for the price of diesel-electricity. 

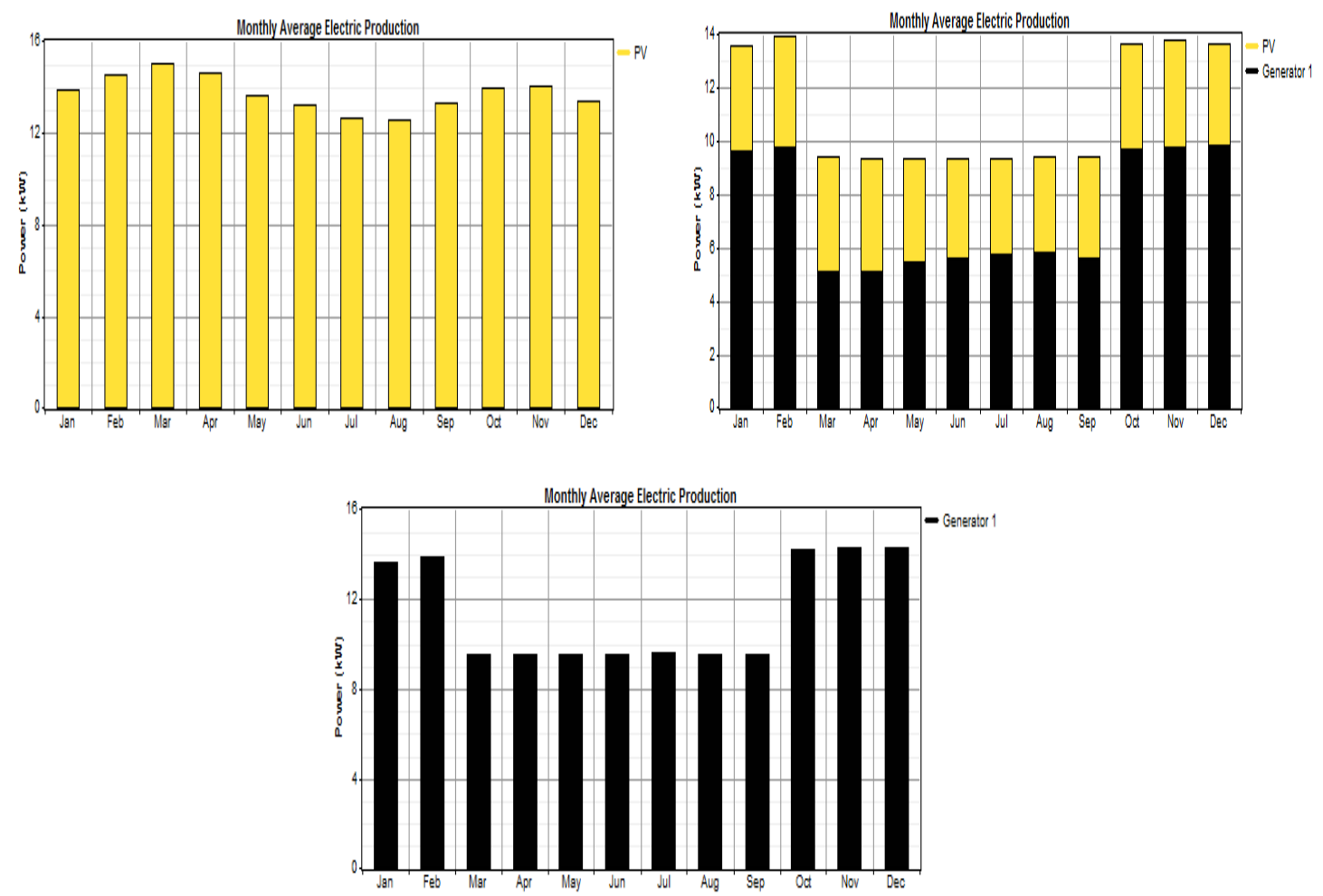

Figure 4: Monthly Average Electric Production for the three different System solutions.

\subsubsection{Value of emitted $\mathrm{CO}_{2}$}

The reduced amount of $\mathrm{CO}_{2}$ by the energy system has an economical value, due to the taxes that will paid for each $\mathrm{kg}$ of $\mathrm{CO}_{2}$ that is emitted, even if there are at the moment no policies that control the emission of $\mathrm{CO}_{2}$ in Sudan. The value for the $\mathrm{CO}_{2}$ reduction is set to $15 \$$ /ton.

\subsubsection{Capital cost}

Table 3 below shows the capital cost or the specific purchase price of the different components of the system (PV systems, Storage Batteries, Inverters and Diesel Generator):

Table 3: The Capital Cost

\begin{tabular}{cccccccc}
\hline Unit & Size & Capital Cost & Ref. & Unit & Size & Capital Cost & Ref. \\
\hline PV panels & $1.0 \mathrm{~kW}$ & $5000 \$$ & {$[8]$} & Inverters & $1 \mathrm{~kW}$ & $746.4 \$$ & {$[10]$} \\
$\begin{array}{c}\text { Diesel } \\
\text { Generator }\end{array}$ & $1.0 \mathrm{~kW}$ & $972.7 \$$ & {$[9]$} & Batteries & 1 set (3000 Ah) & $1088.2 \$$ & {$[11]$} \\
\hline
\end{tabular}

The PV panel's cost that mentioned above is the total cost of the system including panel, installation, connection to the house and so on, the panel's cost is about half of that.

\subsubsection{Cost of Replacement, Maintenance and Fuel}

The replacement cost is the cost of equipment that is purchased to replace a component when its lifetime is shorter than the project time set for this financial analysis. The solar cells have not to be replaced, but the inverters will be replaced after 15 years, battery's lifetime indicated in Figure 3. Battery's lifetime is greater when using PV standalone than the other systems because the number of batteries that used is four times greater, also the battery's annual throughput (the amount of energy that cycled through the battery bank /year) of this system is two times greater. Table 4 shows the replacement cost of the different components: 
Table 4: The inputs of the specific Replacement Cost

\begin{tabular}{cccccc}
\hline Unit & Size & Replacement Cost & Unit & Size & Replacement Cost \\
\hline PV panels & $1.0 \mathrm{~kW}$ & 0 & Inverters & $1.0 \mathrm{~kW}$ & $\$ 746.4$ \\
Diesel Gen. & $1.0 \mathrm{~kW}$ & $\$ 680.9$ & Batteries & 1set (3000 Ah) & $\$ 1088.2$ \\
\hline
\end{tabular}

The operating and maintenance (O\&M) cost of the PV panel is expected to be $\$ 0.45$ per $\mathrm{m}^{2} /$ year, [12], Table 5 shows the maintenance cost for the rest of the components:

Table 5: The Inputs of the Periodic Maintenance Cost

\begin{tabular}{cccccc}
\hline Unit & Size & O\&M Cost $\$$ & Unit & Size & O\&M Cost \\
\hline PV panels & $1.0 \mathrm{~kW}$ & $\$ 4.09 / \mathrm{yr}$ & Inverters & $1.0 \mathrm{~kW}$ & 0 \\
Diesel Gen. & $1.0 \mathrm{~kW}$ & $\$ 0.078 / \mathrm{hr}$ & Storage Batteries & 1 set $(3000 \mathrm{Ah})$ & $\$ 20 / \mathrm{yr}$ \\
\hline
\end{tabular}

The total operating cost is the sum of the annual operation and maintenance cost, and the annualized replacement cost for remaining time of the equipment. The price of Diesel used in this study was selected based on the actual market price of 2006, for gasoline and Diesel in northern Kurdufan which was approximately (1.35 \$/gallon), while the cost in villages is about (1.44 \$/gallon) [13]. The total annual O\&M costs are shown in Figure 3, showing the large difference between PV stand-alone at the Diesel system.

\section{Results}

A summary of the optimized results of the different categories are listed in Table 6. Based on the results, the selected economical evaluation methods will be discussed as shown below. It is interesting to note, that the Hybrid system shows the lowest Net Present Value of all the systems investigated. The systems are compared by means of three types of cost analysis, all three calculated using standard methods and standard definitions:

- $\quad$ Net Present value NPV

- $\quad$ Payback Period (straight payback)

- $\quad$ Levelized Cost of Energy (COE)

Table 6: Summary of the Simulation Results

\begin{tabular}{cccccccc}
\hline System & $\begin{array}{c}\text { Ann. } \\
\text { Saving \$ }\end{array}$ & NPV \$ & $\begin{array}{c}\text { Payback } \\
\text { period }\end{array}$ & $\begin{array}{c}\text { Levelizd } \\
\text { COE (\$) }\end{array}$ & $\begin{array}{c}\text { Excess } \\
\text { Electricity }\end{array}$ & $\begin{array}{c}\mathrm{CO}_{2} \text { Emission } \\
\mathrm{kg} \mathrm{CO}_{2} / \mathrm{kWh}\end{array}$ \\
\hline PV Stand-alone & 29774.1 & 433729 & 13.1 & $\mathrm{yr}$ & 0.399 & $18.6 \%$ & 0 \\
Hybrid System & 24031.8 & 279380 & 8.3 & $\mathrm{yr}$ & 0.251 & 0 & 0.507 \\
Diesel Gen. & 22113.1 & 284672 & 5.0 & $\mathrm{yr}$ & 0.251 & 0 & 0.879 \\
\hline
\end{tabular}

The annual saving is based calculated from the amount of the electrical energy produced per year and delivered to the hotel and in the case of the stand-alone system also to the neighbors. This is multiplied by the cost of electricity produced by the Diesel system (which is $0,251 \$ / \mathrm{kWh}$ ).

\subsection{Net Present Value NPV}

As shown in Table 7, the initial cost of the PV Stand-alone system is the highest among all the systems-almost 3 times compared with the hybrid system, and more than 8 times compared with the Diesel system. However, the PV system uses no fuel, and the other systems pay from $\$ 7000$ and $\$ 12000$ per year, respectively. Also, Diesel generators need to be replaced approximately 4 times during the project's lifetime. The storage battery holds for about 14 years in the stand-alone system; it needs to be changed 2 times at least for the other systems. 
At the end of the project's economic running time, the total NPV of the PV stand-alone system is only about 1.5 times of both the hybrid and the diesel systems total NPV cost.

Table 7: The details of the NPV cost.

\begin{tabular}{ccccc}
\hline & Initial Capital \$ & O\&M Cost \$ & Annual Fuel \$ & Total NPV \$ \\
\hline PV Stand-alone system & 387064 & 1204 & 0 & 433729 \\
Hybrid System & 137703 & 335 & 7014 & 279380 \\
Diesel Generator & 47430 & 266 & 12285 & 284672 \\
\hline
\end{tabular}

It can be seen that the NPV-analysis has a limited effect on the economical evaluation on the two systems (stand-alone and the hybrid), in spite of the big difference in the initial costs.

\subsection{Payback period}

The payback period can give an indication to the investor how fast he can get his money back. From the data of Table 6, one can notices that while the minimum time that is needed to recover the investment cost of the hybrid system and the Diesel generator system are 8.3 and 5 years respectively, the stand-alone PV system needs 13.1 years to recover its cost.

\subsection{The Levelized Cost of Energy COE}

The levelized cost of energy COE gives the average cost of producing one kWh of electricity, including all the different cost contributions. Table 7 shows that the PV stand-alone system has the highest COE per kWh (\$ 0.399), while the COE of both Diesel and hybrid systems are the same (\$0.251). This seems to be reasonable in respect to the NPV-levels of the systems.

\subsection{Sensitivity analyses}

In such analyses, the results are strongly influenced by the quality of the input. Therefore, sensitivity analyses can illustrate this influence. In our study, we have increased the oil price by $20 \%$, and reduced the PV panels cost by $20 \%$. In all cases, there was no change of the ranking of the three types of systems, but of course the gap becomes smaller. The Hybrid system turns out to be the system with lowest COE $(0.25 \$ / \mathrm{kWh})$ in both cases, the PV standalone system remaining the system with the highest COE $(0.359 \$ / \mathrm{kWh})$.

\section{Discussion and/or Conclusions}

Three categories of the power systems are suggested by this study to solve the instability of the power supply of Rosa Park Hotel in Khartoum, and to replace the grid/Diesel current options. From the simulation results, and the analysis of the annuity calculations, one can notice that both the stand-alone and hybrid PV/Diesel systems can be used and both of them sound profitable, with a straight payback period less than 9 years for the hybrid system, and less than 14 years -which is almost half of the project's lifetime- for the stand-alone system.

The study shows also that, the PV solar energy can be use separately or together with the Diesel generator as a replacement energy resource, to solve the power supply problems, and also to reduce the need of carbon-based energy. Due to the high initial cost of the installation of the stand-alone system, based on the economical evaluation of the systems, we think, the hybrid system is more viable option compared to the use of the Diesel generator separately. However, the selection of such system should not be evaluated based only on the economic feasibility; also the expected environmental and social benefits need to be considered, since the three elements are important for the sustainable development assessment of any project. 
From the economical analysis it is easy to notice that, the stand-alone PV is the most expensive way to generate electricity among the three systems, but in terms of carbon dioxide emissions, it is more environmentally sound because the system emits no $\mathrm{CO}_{2}$ during the electricity production, while both the Diesel generator system and the hybrid system emit considerable amounts of the greenhouse gas, about $0.879 \mathrm{~kg}$ of $\mathrm{CO}_{2} / \mathrm{kWh}$ and $0.507 \mathrm{~kg}$ of $\mathrm{CO}_{2} / \mathrm{kWh}$ respectively. According to Simon, these emissions from fusel fuel-powered generators present a 'cost' that should be factored into energy system choices [14]. This might be difficult to be achieved in developing countries such as Sudan, but if the government would make the cost per kWh from the power generator more transparent and would remove the fuel subsidy, PV systems would be a competitive option also in this country [13].

\section{References}

[1]O. Abdeen, Compilation and Evaluation of Solar and Wind Energy in Sudan, Renewable Energy Vol. 12 (No.1), 1997, pp 47.

[2] Greenwich Mean Time website, (sited 29-10-2009, 21.58)

[3] Rosa Park Hotel website (sited 24/08/2010) http://www.rosaparkhotels.com/Photos.html

[4] (EUREC), PV in Building: The Art of Merging, the European Renewable Energy Research Centres Agency, 1997.

[5] Vanggaard, Morten Eghøj, Lund, Dan Toste, Design of a standalone PV system for Greenland, Dep. of Civil Engineering, Danmarks Tekn. Univ. (DTU), 2009, M.Sc: 7\&8.

[6] The NASA Surface Meteorology and Solar Energy web site -.http://eosweb.larc.nasa. gov/cgibin/sse/homer.cgi?email=asim214@yahoo.com\&step=1\&lat=15+31\&lon=32+35\&sub

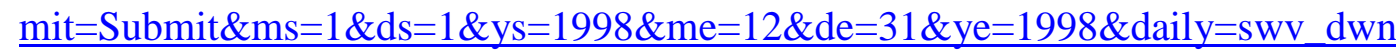

[7] National Renewable Energy Lab., Getting started Guide for HOMER Vers. 2.1,2005.

[8] Wholesale Solar Company website: sited 16/08/2010 http://www.wholesalesolar.com/products.folder/module-folder/bp/bp380U.html.

[9] Just Generators website: sited 16/08/2010

http://www.justgenerators.co.uk/pages/Stephill_SSDX11_3phase.htm.

[10] Wholesale Solar Company website: sited 16/08/2010. http://www.wholesalesolar.com/products.folder/inverter-folder/XP1100-12.html

[11] Wind \& Sun company website: sited 16/08/2010.

http://www.windandsun.co.uk/Prices/prices_batteries.htm

[12] Joan M. Ogden, Cost and performance sensitivity studies for solar photovoltaic / electrolytic hydrogen systems, Solar Cell, 30, 1991 pp 517.

[13] B. Croxford, M. Rizig, Is photovoltaic power a cost-effective energy solution for rural peoples in western Sudan? Solar 2006: renewable energy, key to climate recovery, American Solar Energy Society.

[14] International Energy Agency (IEA), Guidelines for economic evaluation of building integrated PV, Report IEA PVPS T7-05: 2002 p.12. 